\title{
Actors' Collaboration to Manage Disasters in Cilacap District Central Java Province Indonesia
}

\author{
Rudi Subiyakto ${ }^{1}$, Sri Suwitri ${ }^{2}$, Endang Larasati ${ }^{3}$ Prayitno $^{4}$ \\ \{rudi_subiyakto@yahoo.co.id ${ }^{1}$ \} \\ Universitas Maritim Raja Ali Haji, Indonesia ${ }^{1}$ \\ Universitas Diponegoro, Indonesia ${ }^{2,3}$ \\ Regional Disaster Management Agency of Wonosobo District, Indonesia ${ }^{4}$
}

\begin{abstract}
The province of Central Java has areas spreading to 35 Districts/Cities, of those Districts/Cities, there is an area which based on Indonesia's Disaster Risk Index (IRBI) year 2016 has a quite high risk index, that is Cilacap District which occupies the 17th position nationally and first number for the position of 35 Districts/Cities located in Central Java within score number 132 (categorized as highly vulnerable class). Risk disasters occur in Cilacap District covering earthquake, tsunami, flood, landslide, tidewater, whirlwind and drought. Within such conditions, it is needed some actors' collaborations to manage disaster that can hit the Cilacap District at any time. This research aims to describe actors' collaboration to implement disaster management in Cilacap District Central Java Province. Research method which was used was a qualitative method by seeing the phenomena of actors' collaboration to implement disaster management. Result of the research shows that from the mapping of actors can be seen that there are a core actor and supporting actors in the process of implementation of disaster management in Cilacap District. Then, the actors involved in the operation do collaboration by means of communication, coordination, and cooperation under the control of Regional Disaster Management Agency (BPBD) as the leading sector.
\end{abstract}

Keywords: Actors' Collaboration, Disaster Management, Cilacap District.

\section{Introduction}

Indonesia is one of 6 ( $\mathrm{six}$ ) countries vulnerable to natural disasters. The other five countries are Japan, China, Nepal, Philippine, and Taiwan. Based on the condition Indonesia now is in the third number as a country vulnerable to natural disasters [1].

In the context of Cilacap District, data from Regional Disaster Management Agency (BPBD) of Cilacap District describe Cilacap District as an area having Indonesian's Disaster Risk Index the highest one in the area of Central Java Province, on the $17^{\text {th }}$ position nationally and the $1^{\text {st }}$ position from 35 districts/cities in the area of Central Java Province with the score value 132 (included as highly vulnerable class to disaster risks including flood, tidewater, landslide, drought, typhoon, earthquake and tsunami (BPBD of Cilacap District Year 2016).

Data from Regional Disaster Management Agency of Cilacap District shows that the financial loss for natural disasters occurred in Cilacap District along 2016 reached the number Rp71.5 billion. The number of loss was because that along that year Cilacap suffered from tidewater, flash flood and swamp, landslide and whirlwind. The highest loss number caused by tidewater in Cilacap south coastal line reached Rp40.090 billion. Flash flood and swamp to the 
last November occurred 25 times spreading out on 64 villages in Cilacap District with the loss number reached Rp20.899 billion. The third biggest loss was caused by landslide which was reaching Rp7.662 billion. It is written in the data from Regional Disaster Management Agency (BPBD) that the disaster of landslide occurred up to 57 times on 105 villages. (Accessed on September $29^{\text {th }}, 2017$ at 22.00 West Indonesian Time Zone).

Result from pre-research conducted by the researcher shows that there are some problems related to the implementation of the policy on natural disaster management matters in Cilacap District, those are: firstly, in the case of management and handling of disasters occurred in a certain area where the district government has formed a coordination unit for disaster management implementer consisted of local government element, business world and community, but in the implementation, the coordination between stakeholders has not yet been ideally work; secondly, as a form of realization for disaster management, disaster mapping has been often performed, but the local government of Cilacap District is not yet optimum in anticipating the disasters. Besides, when occurred a disaster in a certain area, the funding for handling operational activities, means and infrastructure facilities for evacuation, transportation, reconstruction and rehabilitation for post-disasters is actually been budgeted but the fact it is always late to implement. Because of the condition, the writer wants to uncover and analyze the actors' collaboration in the implementation of disaster management in Cilacap District Central Java Province.

\section{Research Method}

In this research the writer used qualitative method by seeing the process of collaboration among the involved actors and mapping it to the implementation of disaster management in Cilacap District. According to Creswell [2], data collecting in a qualitative research was done through observation, interview, documentation study, and audiovisual materials. In this research, data collecting was done by interview, observation and documentation related to the disaster matters.

\section{Result and Discussion}

\subsection{Actors involved in the disaster management in Cilacap District Central Java Province}

According to Sabatier [3] in analyzing how far the policy networks able to predict policy changes, so it needs to define the important dimension of policy networks. Firstly, because there is no actor who is fully able to influence the process of decision making, but the actor coalition should be being main element in the policy networks [4][5][6]. Secondly, based on the explorative review on the literature related to policy networks, then three elements are seemingly being important factors, those are conflict, collaboration, and power. The three elements are not only the most important element in policy networks [7][8][9][10], but also some most fundamental concepts in political science and public policy.

Based on the actor mapping there are some actors involved in the implementation of disaster management in Cilacap District, those are consisting of the actors from governmental elements, such as: Regent, District Secretary, Regional Disaster Management Agency (BPBD), Agency for Regional Development (Bappeda), Health Service, Ministry of PUPR, Social 
Service and Directorate General of Highway Construction and Maintenance. Community elements, such as: the youth of disaster conception (Tagana), community center of Indonesian police's partners, Majenang Rescue Outdoorsman (Parma), Muhammadiyah Disaster Management Center (MDMC), Banser disaster conception (Bagana), Banyumas Rescue, Simpala Muda and Indonesian inter residents' radio (RAPI). Business world, such as: Pertamina RU IV Cilacap, PT Holcim Tbk, PT Pangan Mas Inti Persada, PT SAP PLTU and PT Pelindo Tanjung Intan. To be clearer, see figure below:

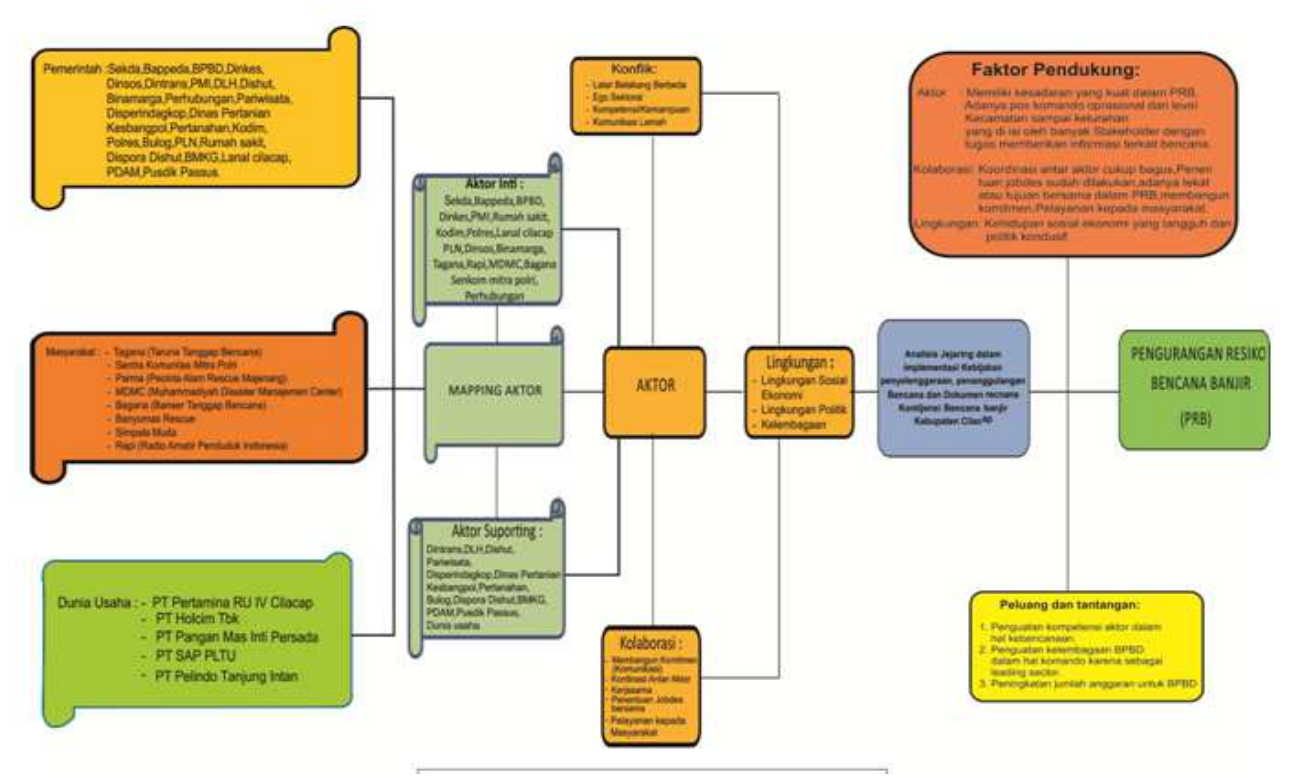

Fig. 1. Actors Mapping on Implementation of Disaster Management in Cilacap District Source: Result of the Research Year 2018.

\subsection{Inter-Actors Collaboration Process on Implementation of Disaster Management in Cilacap District Central Java Province}

Actors involve on implementation of disaster management in Cilacap District have different backgrounds so they have different roles based on the need and function in the area. In this case, Regional Disaster Management Agency (BPBD) of Cilacap District takes role as leading sector, thus the process of collaboration works within the clear instruction of thus agency so it can minimize conflict susceptible to occur in the work area. This is as stated by Head Section of Awareness Conception of Regional Disaster Management Agency (BPBD) of Cilacap District:

"All the involved actors for the work of disaster management in Cilacap District are surely been known by the Local Government of Cilacap District and Regional Disaster Management Agency (BPBD) because the rules related to the disaster matters in Cilacap District say so, so there will be no stowaway or other party involved in the process of implementation." (Arif Praptomo, S. IP, M.M, January $\left.15^{\text {th }}, 2019\right)$. 
It cannot be denied that within the various problems experienced by local government in the stage of planning natural disaster management, the government of Cilacap District strives to do collaboration with other parties, by referring to the local regulation of Cilacap District No, 1 Year 2012 about the implementation of disaster management which is done not only by the government of Cilacap District, so the government of Cilacap District collaborate with the actors involving people communities and business world to manage the disaster. This is stated by the Head of Daily Execution of Regional Disaster Management Agency (BPBD) of Cilacap District:

"Government of Cilacap District in implementing disaster management is always taking cooperation with the parties from outside of government, such as people communities and business worlds because it is impossible to work alone within the disaster escalation often to come. Praise be to Allah; between the government and non-government they are able to cooperate and work together. Conflict is surely to come, but it is less in risk to disturb the process of implementation of disaster management because basically there has been a regulation that can be referred to as a manual for its operation." (Drs. Tri Komara Sidhy, M.M. January 17 $7^{\text {th }}$ 2019).

From the statement above, it describes that the people communities and business worlds are the other parties outside the government who move to support efforts in reducing disaster risks in Cilacap District. As actors outside the government, people communities and business worlds take role to reduce disaster risks in the level of Cilacap District which provides coordination mechanism to improve collaboration for many interest functionaries to do continuing activity planning on disaster management through consultative and participative processes in harmony with the implementation of the framework as is written in the local regulation.

The implementation of disaster reduction in Cilacap District gives contribution to reduce disaster risks through advocating, supervision, facility, and consultation enable to give a way for disaster risk reduction for all of the interest functionaries to make an aware and sturdy to disaster communities. A form of well-coordinated collaboration among different governmental and non-governmental institutions in the situation of aware to manage disasters surely will determine the performance of the actors when managing the disaster.

The rising of different point of views/perceptions among the actors further can create egosector and less faithful toward the performance/effort of the other actors. This point of view can be related to the priority scale matters on whom to accept help or certain area to take first for the action of disaster handling.

The next is the availability for weak financial resources or funding. The actors, either from government of non-government, to do their activities, they still depend on the budget from government. The availability for human resources and engineer resources are also still limited. The less of this resource in number causes the disaster management is being hampered. This is because of the stacks of work to do by the limited number of personnel.

\section{Conclusion}

There are some conclusions for this study, those are: from the result of actors mapping shows that there are a core actor and supporting actors in the process of implementation of 
disaster management in Cilacap District; second, the actors involved in their operation they do collaboration by means of communication, coordination and cooperation under the control of Regional Disaster Management Agency (BPBD) as the leading sector; and third, coordination between actors is quite good, the determination for job description has been done, the existence of strong will or interest to the same direction to Disaster Risk Reduction build the commitment and service to the society.

Then, there are some recommendations to make effective collaborations, those are: Firstly, it is needed the policy to encourage intent communications done by the actors involved in the implementation of the work of disaster management in Cilacap District; and secondly, it is needed support from all parties to improve numbers of funding provides for Regional Disaster Management Agency to realize the operational of the implementation of disaster management in Cilacap District so the purpose to reduce risk disaster can run ideally.

\section{References}

[1] R. Avin, "Ini 6 Negara Paling Berpotensi Terjadi Bencana Alam,” Iya Newsp., 2016.

[2] J. W. Creswell, "Research Design: Quali-tative \& Quantitative Approaches SAGE Publications," Inc. USA, 1994.

[3] M. Fischer, "Policy Network Structures, Institutional Context, and Policy Change," Int. Conf. Public Policy, 73(June), pp. 1-32, 2013.

[4] P. A. Sabatier and H. C. Jenkins-Smith, Policy change and learning: An advocacy coalition approach. Westview Pr, 1993.

[5] H. Kriesi, E. Grande, R. Lachat, M. Dolezal, S. Bornschier, and T. Frey, "Globalization and the transformation of the national political space: Six European countries compared," Eur. J. Polit. Res., vol. 45, no. 6, pp. 921-956, 2006.

[6] P. A. Sabatier and C. M. Weible, "The advocacy coalition framework," Theor. policy Process, vol. 2, pp. 189-220, 2007.

[7] R. A. W. Rhodes, "The new governance: governing without government," Polit. Stud., vol. 44, no. 4, pp. 652-667, 1996.

[8] D. Knoke, F. U. Pappi, J. Broadbent, and Y. Tsujinaka, Comparing policy networks: labor politics in the US, Germany, and Japan. Cambridge University Press, 1996.

[9] H. T. A. Bressers and L. J. O'Toole Jr, "The selection of policy instruments: A network-based perspective," J. Public Policy, vol. 18, no. 3, pp. 213-239, 1998.

[10] S. Adam and H. Kriesi, "The network approach," Theor. policy Process, vol. 2, pp. 189-220, 2007. 